https://helda.helsinki.fi

\title{
Law-Based Commodification of Private Debt
}

\author{
Juutilainen, Teemu
}

2017

Juutilainen , T 2017 , ' Law-Based Commodification of Private Debt ' , European Law Journal , vol. 22 , no. 6 , pp. 743-757 . https://doi.org/10.1111/eulj.12210

http://hdl.handle.net/10138/308560

https://doi.org/10.1111/eulj.12210

cc_by_nc

acceptedVersion

Downloaded from Helda, University of Helsinki institutional repository.

This is an electronic reprint of the original article.

This reprint may differ from the original in pagination and typographic detail.

Please cite the original version. 


\title{
Law-Based Commodification of Private Debt
}

\author{
Teemu Juutilainen ${ }^{*}$
}

\begin{abstract}
This article looks back in history to understand how private debt developed into the kind of tradeable asset, or commodity, that it is today. The article theorises that development, distinguishing in it three discrete but overlapping modes of commodification, namely propertification, impersonalisation and risk abstraction. The three modes shed light on changes in debt as a legal institution and in the economic and social functions of debt. Finally, the article shows that commodification of private debt is not just a phenomenon of the past, but something to be taken into account in future law-making, where the three modes of commodification may help to recognise particular opportunities and risks. This is illustrated by two actions included in the Commission's Capital Markets Union project, one regarding cross-border assignments of claims, the other the European securitisation market.
\end{abstract}

\section{Introduction}

For contemporary market economies, debt is a tradeable asset, something capable of being sold and bought in different forms. In effect, debt has become a commodity. For proof, one only needs to think of the prevalence of financing techniques based on assignment of receivables (i.e. rights to payment of a monetary sum, a subset of 'claims'), such as factoring and securitisation. ${ }^{1}$ A closely related matter is that debt is generally regarded as a type of intangible property. ${ }^{2}$ In notions of debt as a commodity or property, debt is viewed from the creditor side, as receivables or claims.

The notion of debt as a commodity is essential background to several other themes in this special issue. Today's networks of debt could not have developed without extensive and in part excessive

\footnotetext{
* Postdoctoral researcher at the University of Helsinki, Faculty of Law. Availability of web references checked on 1 December 2016. I thank Dr Orkun Akseli for helpful comments on the first draft of this article, and Professor Agustín José Menéndez for thorough review. The article is a product of the project 'European Bonds: The Moral Economy of Debt', funded by the Academy of Finland and the University of Helsinki.

${ }^{1}$ Factoring generally means conversion of trade receivables ('invoices') into cash by selling them to a finance company, called a 'factor'. Securitisation involves pooling together of receivables from mortgages or other loans and refinancing that pool, usually by selling it to a specially established company or other entity, called a 'special purpose vehicle' or 'SPV', which finances the purchase by issuing debt securities backed by the pool (i.e. the income stream generated by the receivables), to be bought by investors in capital markets. See United Nations Commission on International Trade Law, UNCITRAL Legislative Guide on Secured Transactions (United Nations, 2010), Introduction, at paras. 31-37, available at http://www.uncitral.org/pdf/english/texts/security-lg/e/09-82670_Ebook-Guide_09-04-10English.pdf. The concept of assignment may cover, besides outright transfers of claims, transfers of claims by way of security, and (other) security rights over claims. See Article 14 para. 3 of Regulation (EC) No 593/2008 of the European Parliament and of the Council of 17 June 2008 on the law applicable to contractual obligations (Rome I), OJ L of 4 July 2008, 616.

${ }^{2}$ See C. Lebon, 'Property Rights in Respect of Claims', in S. (J.H.M.) van Erp and B. Akkermans (eds.), Cases, Materials and Text on National, Supranational and International Property Law (Hart Publishing, 2012), 365-423; A. Flessner and H. Verhagen, Assignment in European Private International Law: Claims as property and the European Commission's 'Rome I Proposal' (Sellier European Law Publishers, 2006), at 2-7.
} 
trading in debt, including in the shape of highly engineered financial products. ${ }^{3}$ Without those networks, and the resulting interdependences between individuals, enterprises and states, we would have less reason to inquire into the European community of debt. More generally, the commodity nature of debt must be recognised as a central precondition for financialisation. ${ }^{4}$ Importantly, though, the origins of current commercial and financial practices suggest that rather than a necessary quality of debt, tradeability is historically contingent.

This article examines commodification of private debt, i.e. debt owed by private actors. As a working definition, commodification of debt is understood as transformation of debt into a tradeable asset, or a more easily tradeable one. That transformation is a historical but in important respects still ongoing process. The article focuses on the legal aspects of the process, recognising that its most significant developments so far have been caused or enabled by changes in the law, which justifies speaking of law-based commodification. Accordingly, the article traces changes in debt as a legal institution, and resulting changes in the economic and social functions of debt. ${ }^{5}$

Of course, commodification is not a new concept ${ }^{6}$ nor indeed is commodification of debt. The above working definition of commodification of debt may differ from earlier definitions in at least two respects: First, the working definition implies a long historical perspective. ${ }^{7}$ This is necessary because developments significant to the article span over two millennia. ${ }^{8}$ Second, the working definition is intended, to the extent that this is possible, to be free from pre-existing theoretical assumptions on the nature and implications of the developments examined here. ${ }^{9}$ Thus, the degree of commodification of debt at a given time simply equals the degree of tradeability of debt, although the closer content of tradeability is a complex matter as this varies over time.

\footnotetext{
${ }^{3}$ See A. Turner, The Turner Review: A regulatory response to the global banking crisis (Financial Services Authority, United Kingdom, 2009), at 14-20, available at http://www.fsa.gov.uk/pubs/other/turner_review.pdf; M. Blyth, Austerity: The History of a Dangerous Idea (Oxford University Press, 2013), at 21-31, 84-87.

${ }^{4}$ See G.A. Epstein, 'Introduction: Financialization and the World Economy', in G.A. Epstein (ed.), Financialization and the World Economy (Edward Elgar, 2005), 3-16, at 3. Epstein defines financialisation as 'the increasing role of financial motives, financial markets, financial actors and financial institutions in the operation of the domestic and international economies'.

${ }^{5}$ For a general call for this kind of research, see R. Swedberg, 'On Legal Institutions and Their Role in the Economy', in F. Dobbin (ed.), The Sociology of the Economy (Russell Sage Foundation, 2004), 74-92, at 74-75.

${ }^{6}$ See U. Salam, 'Commodification, capitalism and crisis', in B. Harriss-White and J. Heyer (eds.), Indian Capitalism in Development (Routledge, 2015), 153-169 at 153. Salam defines commodification as 'the process by which a thing or activity is transformed into a commodity for the purposes of exchange in a market' and notes that it 'has always been at the heart of the study of capitalist development'.

${ }^{7}$ Cf. V. Finch, 'Corporate Rescue in a World of Debt', (2008) Journal of Business Law 756-777, at 756-764. Finch does not actually define 'commodification of debt', but uses the term in connection with various late 20th and early 21 st century developments of financial capitalism, especially those resulting in the 2007-2008 credit crunch.

${ }^{8}$ For a similar temporal perspective, with the aim of providing 'a history of the present', see S. Frerichs and T. Juutilainen, 'Rome Under Seven Hills? An Archaeology of European Private Law', in S. Börner and M. Eigmüller (eds.), European Integration, Processes of Change and the National Experience (Palgrave Macmillan, 2015), 73-99, at 74.

${ }^{9}$ Cf. S. Soederberg, 'Student Loans, Debtfare and the Commodification of Debt: The Politics of Securitization and the Displacement of Risk', (2014) 40 Critical Sociology 689-709, at 691. From a historical-materialist perspective, Soederberg perceives commodification of debt as 'a tension-ridden, class-based strategy that emerges from the contradictions inherent to the credit system within the wider dynamics of capital accumulation', and as involving processes underpinned by 'highly unequal and exploitative social relations of power'. Further, she argues that 'the neoliberal state', by its ideology and institutions, mediates, depoliticises and legitimates 'the displacement of social risk that occurs through the commodification of debt'.
} 
In the following, commodification of private debt is discussed in three main sections, II to IV. Section II puts together historical material for further analysis in the subsequent sections, from Roman law up until contemporary law. Early and classical Roman law is presented as a zero point in the commodification of debt, due to its extremely person-bound understanding of obligations. This is followed by a series of historical points in which changes in the law gradually enabled and facilitated trading in debt. Since such an account could never be complete, the aim is to collect representative instances, in snapshot style.

Section III draws on the historical material, distinguishing three discrete but overlapping modes in which commodification of private debt may occur. These are termed propertification, impersonalisation and risk abstraction. It is argued that each of these modes represents a qualitative change in debt as a legal institution. Additionally, quantitative changes should be observed because each mode may have advanced more or less by a given time. The modes also open avenues for discussion of changes in the economic and social functions of debt, and of the broader effects of those changes. In this sense, the modes arguably unveil parts of the 'hidden social theory' of laws on debt relations, i.e. the often unarticulated background assumptions of those laws on the nature of debt as a social relationship. ${ }^{10}$

Section IV shows that commodification of private debt is not just a phenomenon of the past, but something that is very much with us, and likely to remain so in the future. Accordingly, it should be factored in by lawmakers. To be sure, commodification cannot be regarded as complete with respect to any of the three modes mentioned above. Decisions on future law may affect commodification of debt, advances and retreats being equally possible as to each of the modes. In other words, the course of commodification, or de-commodification for that matter, is indeterminate but to a degree could be steered if not controlled by law. Importantly, the three modes help to recognise opportunities and risks in future law-making. These points are illustrated by two actions included in the Commission's Capital Markets Union project, namely attempts to solve cross-border problems with respect to assignment of claims and to revive the European securitisation market. ${ }^{11}$ Section V presents conclusions.

\section{Past: Instances of Commodification So Far}

\section{A Roman law}

In striking contrast to laws enabling current commercial and financial practices, early and classical Roman law regarded transfer ('cession') of claims as unthinkable. A metaphysical and a functional

\footnotetext{
${ }^{10}$ On the notion of 'hidden social theory', see K. Tuori, Ratio and Voluntas: The Tension Between Reason and Will in Law (Ashgate, 2011), at 200. Tuori discusses this notion as one of the constitutive elements of legal theories, as 'the conception of social relationships under regulation which the legal theory implies (the theory's factual commitments)'. ${ }^{11}$ Communication from the Commission to the European Parliament, the Council, the European Economic and Social Committee and the Committee of the Regions: Action Plan on Building a Capital Markets Union, COM(2015) 468 final, 30 September 2015, at 21-23, available at http://ec.europa.eu/finance/capital-markets-union/docs/building-cmuaction-plan_en.pdf.
} 
explanation can be given for that unthinkability. The metaphysical explanation concerns how the nature of obligation was understood, namely as 'something highly personal, a vinculum iuris that attains its individuality by virtue of having been created between two specific parties'. Accordingly, claims were thought to be inseparable from the one particular creditor-debtor relationship. ${ }^{12}$ As a consequence, 'transfer' (an intentional anachronism for the purpose of presentation) of a claim could not have resulted in the same claim being established between a new creditor ('transferee') and the debtor. The functional explanation recalls that back then 'execution on the person of the debtor [was] a living institution'. Therefore, the law could not 'allow a creditor to transfer his right to another without the consent of the debtor, thereby perhaps substituting a harsh creditor for a mild one'. ${ }^{13}$

Rome was no exception to the rule that 'each society in which commerce plays a role sooner or later has to face a strong demand to increase the circulation of credit'. ${ }^{14}$ Roman law managed to do without transfer of claims by making use of two other legal institutions with partly similar results, namely novation and procedural representation. Novation meant authorising the debtor to assume a new obligation with the same content towards a new creditor. The arrangement was impractical, among other things because it depended on the debtor's cooperation. In procedural representation, the initial creditor appointed the 'transferee' as his cognitor (i.e. attorney) or procurator (i.e. agent) in rem suam (i.e. acting in his own interest), thus authorising the 'transferee' 'to sue the debtor in his own name and to keep whatever he received'. This left the 'transferee' in a precarious position because the initial creditor, who remained the actual creditor, could still frustrate the arrangement, say, by instituting a claim himself, by accepting performance from the debtor or by releasing the debtor from the obligation. Further, the initial creditor could revoke the 'transferee's' authority to sue. Such acts by the initial creditor were possible until the start of a suit, the litis contestatio, where the new creditor replaced the initial creditor (the so-called novatio necessaria). To some extent, though, the 'transferee's' position could be ameliorated through a cautio, whereby the initial creditor stipulated not to interfere with it. ${ }^{15}$

Under imperial law, from Antoninus Pius onwards, the 'transferee's' position (as cognitor or procurator in rem suam) was gradually strengthened, i.e. made increasingly independent of the initial creditor, by the grant of an actio utilis ('adapted action') against the debtor in various situations. Eventually these actions were made available whenever a transfer of a claim had been intended by the parties, irrespective of the type of transaction involved. ${ }^{16}$ Development of

\footnotetext{
${ }^{12}$ R. Zimmermann, The Law of Obligations: Roman Foundations of the Civilian Tradition (Oxford University Press, 1996), at 58-59. On cognitor and procurator, see H.J. Roby, Roman Private Law in the Times of Cicero and of the Antonines, vol. II (Cambridge University Press, 1902), at 376-381.

${ }^{13}$ F. Schulz, Classical Roman Law (Oxford University Press, 1961), at 628. According to Schulz, the same explanation held true for Hellenistic and Teutonic (including English) law.

${ }^{14}$ Zimmermann, n. 12 above, at 59.

${ }^{15}$ Ibid., at 60-62. Footnote omitted from the quoted passage. Cf. Schulz, n. 13 above, at 627. According to Schulz, all reliable sources speak of cognitor, while procurator is Byzantine interpolation. See K. Zweigert and H. Kötz, Introduction to Comparative Law, transl. T. Weir (Oxford University Press, 3rd edn, 1998), at 443.

${ }^{16}$ Zimmermann, n. 12 above, at 62. See Schulz, n. 13 above, at 31. Schulz writes: 'Actio utilis is an action arising from the imitation of another action promised in the Edict. The word utilis means "accommodated", i.e. adapted to a case not covered by the original action.' Cf. P. Birks, The Roman Law of Obligations, ed. E. Descheemaeker (Oxford University Press, 2014), at 214. Birks explains the term differently: 'The spirit, higher principle or policy of the lex is called its utilitas, its social usefulness, its expediency. [...] The "utilitas-motivated" actions were actiones utiles.'
} 
denuntiatio, notification of the debtor by the 'transferee', further improved the 'transferee's' position, eventually excluding the possibility of the debtor to discharge the obligation by performance to the initial creditor. By Justinian's time, 'for all practical purposes assignment as a transfer of the substantive right from the old to the new debtor [sic: what is meant is 'creditor'] (i.e. a singular succession to obligations) had become recognized'. ${ }^{17}$

\section{B From Corpus Iuris Civilis and Ius Commune to National Laws}

Roman law was codified in the Corpus Iuris Civilis in a way that proved unfortunate for later interpreters. The trouble was that the various classical and post-classical phases through which development of the law had passed were 'juxtaposed as existing law'. This resulted in great confusion in medieval legal scholarship and the ius commune. The glossators dealt with contradictions and conflicting sources, probably as logically as they could, by reverting to the old non-transferability dogma. Although the ius commune eventually 'recognized claims as fully transferable items of property', confusion and theoretical disputes continued over the centuries, ending up in national (or nationalising) contexts. For instance, non-transferability was still being defended in 19th century German scholarship, by Christian Friedrich Mühlenbruch in particular, to be refuted by Bernhard Windscheid and Otto Bähr. ${ }^{18}$

Rudolf von Jhering seems to refer to these debates in his Begriffshimmel satire, treating the nontransferability view and its apparent conceptual purity as follows:

[Spirit, an inhabitant of the heaven of jurisprudential concepts, to author-narrator:] As you know, the Roman jurists only perceived cession to be a transfer in the execution, and among us here, there is absolutely no doubt that they were quite right. But the modern legislators and practitioners have made of her the thing that you see before you: the transfer of the claim itself. A succession in a claim — can one imagine anything more absurd? The claim isn't a thing that one has. On the contrary, it is a quality that is. [...] How in the world should one suppose that this quality of being a creditor will be transferred to another? Then beauty, health, strength, and understanding must also be transferable, which would certainly be very desirable but, I am sorry to say, impossible. [...] If B is another person than A, then the claim in the person of B is another thing than in the person of A. It will be cancelled through redemption by the person $\mathrm{A}$ and can therefore only be regenerated in $\mathrm{B}$ by novation. ${ }^{19}$

\footnotetext{
${ }^{17}$ Zimmermann, n. 12 above, at 62-63. Zimmermann reaches this conclusion taking into account the breakdown of classical 'actional law', and the declining relevance of actiones utiles, in post-classical times.

${ }^{18} \mathrm{Ibid}$., at 63-66. See Zweigert and Kötz, n. 15 above, at 444-445. One disagreement between Windscheid and Bähr concerned the need to notify the debtor of an assignment. Bähr's view, according to which notification was not required for transfer of a claim, but a debtor who had paid to the assignor in ignorance of the assignment had a defence, was eventually adopted into the Bürgerliches Gesetzbuch. See Sections 398 and 407.

${ }^{19}$ R. von Jhering, 'In the Heaven for Legal Concepts: A Fantasy', transl. C.L. Levy, (1985) 58 Temple Law Quarterly 799-842, at 837. The German original 'Im juristischen Begriffshimmel: Ein Phantasiebild' is from 1884. The quoted passage is from a discussion at 'the anatomical-pathological concept collection'.
} 
Early commodification of private debt took different paths in different jurisdictions. The English duality of common law and equity well exemplifies jurisdiction-specific structural features that affected development. The common law, where similarly to Roman law non-transferability was the starting position, developed the institution of 'power of attorney' with a function comparable to that of procurare in rem suam, i.e. authorisation to collect on the 'chose in action' in the creditor's name and keep the proceeds. ${ }^{20}$ The courts of equity began to improve the transferee's position in the early 17th century, not directly opposing the old common law rule of non-transferability but in effect draining its content. Finally, the method of 'statutory assignment' was introduced by the Judicature Act 1873 (now in Section 136(1) of the Law of Property Act 1925). ${ }^{21}$

In civil law jurisdictions, the legal thinking of the time when the current codification was enacted may still be recognisable in the content and systematic place of rules on assignment. For example, the French Code civil originally located assignment 'in the law of sales, since the eighteenthcentury jurists always saw the assignor as selling the claim assigned and the assignee as buying it' (see Articles 1689-1701-1). ${ }^{22}$ However, a major amendment introduced in 2016 is located in the general regime of obligations (Articles 1321-1326). In the Italian Codice civile of 1942, reflecting 'abstract' legal thinking and concepts, assignment is found in the title on obligations in general (Articles 1260-1267). ${ }^{23}$

While different paths all led to enabling assignment of claims, divergences in the substantive law of assignment grew wide between jurisdictions, and remain so today. One notable example is the effectiveness of an assignment against third parties, especially the assignor's creditors or subsequent assignees. In some jurisdictions, an assignment is effective against third parties by virtue of mere agreement between the assignor and the assignee (some, typically Germanic jurisdictions distinguish between an underlying obligational agreement and a special in rem agreement to transfer the claim). In others, an additional step is required. That step may consist in, say, notification of the assigned debtor or registration of the assignment. Requirements for thirdparty effectiveness may vary even within the same jurisdiction, depending on the type of assignment (e.g. outright transfers v. transfers for security purposes). ${ }^{24}$

In the above-quoted satire, von Jhering also deals with bearer paper (i.e. a negotiable instrument payable to whoever is in possession of it), in the same tone as transfer of claims:

\footnotetext{
${ }^{20}$ Zweigert and Kötz, n. 15 above, at 443. Cf. E. McKendrick, 'Contract: In General', in A. Burrows (ed.), English Private Law (Oxford University Press, 3rd edn, 2013), 481-612, at 575-576. According to McKendrick, giving effect to assignment was feared to 'lead to maintenance or champerty by encouraging officious intermeddling by $\mathrm{C}$ [assignee] in litigation between A [debtor] and B [creditor]'. Among methods that the common law recognised, he mentions 'a tripartite contract known as novation and acknowledgement by $\mathrm{A}$ to $\mathrm{C}$, by which $\mathrm{C}$ could become entitled to enforce B's claim against A'. Footnotes omitted.

${ }^{21}$ Zweigert and Kötz, n. 15 above, at 444, 452. For detailed accounts, see M. Bridge, Personal Property Law (Oxford University Press, 4th edn, 2015), at 231-260; McKendrick, n. 20 above, at 575-582.

${ }^{22}$ Zweigert and Kötz, n. 15 above, at 448-449.

${ }^{23}$ Ibid.

${ }^{24}$ See B. Lurger, 'Assignment', in J.M. Smits (ed.), Elgar Encyclopedia of Comparative Law (Edward Elgar, 2nd edn, 2012), 104-119, at 107-111, 116-118; British Institute of International and Comparative Law (BIICL), Study on the Question of Effectiveness of an Assignment or Subrogation of a Claim against Third Parties and the Priority of the Assigned or Subrogated Claim over a Right of Another Person: Final Report, at 36-39, available at http://ec.europa.eu/justice/civil/files/report_assignment_en.pdf.
} 
[Spirit, again, to author-narrator:] But even this modern concept of cession, which makes such a mockery of all the principles of logic, is still outdone by the bearer paper you see here before you. Obligation, this pure ideal thing existing only in the legal imagination, is traded by itself. It is captured and imprisoned in a piece of paper - that is the most offensive thing that has befallen her. A thief steals your obligations! A Roman jurist would have believed you were a madman if you had told him this. ${ }^{25}$

To be sure, development of negotiable instruments is another instance of early commodification of private debt. A debt incorporated in that kind of document can be transferred by transferring the document itself. ${ }^{26}$ The origins of negotiable instruments have been widely debated, but they certainly date back many centuries. ${ }^{27}$

\section{Deformalisation of Assignment Laws and Financing Techniques Based on Assignment of Receivables}

From the 1980s onwards, commodification of private debt has proceeded in the shape of a 'deformalisation movement' of assignment laws. This has involved 'the abolition of formal requirements for the validity of assignment or the introduction of a new form of assignment with fewer formalities'. ${ }^{28}$ In particular, the requirement of notification of the assigned debtor has begun to lose ground.

For example, in 1994, Belgium abolished requirements according to which the effectiveness of an assignment against third parties depended on notification of the debtor by a bailiff or acknowledgement of the assignment by the debtor in an authentic deed. Effectiveness against the assigned debtor still requires notification or acknowledgement, though. ${ }^{29}$ Further examples include the French Loi Dailly of 1981 and Code civil amendment of 2016, and the Dutch undisclosed ('silent') assignment introduced in 2004. In these cases, too, notification requirements, where applicable, only concern relations to the assigned debtor. The Loi Dailly enables assignment of business receivables ('professional receivables') to a credit institution by way of a single document (acte de cession or acte de nantissement), mentioning prescribed information on the receivables assigned and fulfilling prescribed formalities. In 1984, this opportunity was extended to future

\footnotetext{
${ }^{25}$ Von Jhering, n. 19 above, at 837.

${ }^{26}$ See Zweigert and Kötz, n. 15 above, at 454. See also Bridge, n. 21 above, at 233. Bridge writes: 'When the common law incorporated from the law merchant jurisdiction over bills of exchange, and other negotiable instruments, it came to recognize exceptionally an assignment taking the particular form of a negotiation of the instrument, which has consequences going beyond those flowing from ordinary assignment.'

${ }^{27}$ See M. Weber, Economy and Society: An Outline of Interpretive Sociology, eds. G. Roth and C. Wittich, transl. E. Fischoff et al. (University of California Press, 1978), vol. 2, at 681-683; J.J. Rabinowitz, 'The Origin of the Negotiable Promissory Note', (1956) 104 University of Pennsylvania Law Review 927-939.

${ }^{28}$ A.F. Salomons, 'Deformalisation of Assignment Law and the Position of the Debtor in European Property Law', (2007) 15 European Review of Private Law 639-657, at 640.

${ }^{29}$ Lebon, n. 2 above, at 391-392; Salomons, n. 28 above, at 645-646. See Articles 1690-1691 of the Belgian Code civil. According to Lebon, notification and acceptance can be informal, but Salomons notes that a requirement of written form can be inferred from the travaux préparatoires. It should also be noted that notification and acceptance play a role in priority contests between competing assignees.
} 
receivables. ${ }^{30}$ The Code civil amendment basically abolished special requirements for third-party effectiveness of an assignment, but requires written form. ${ }^{31}$ The validity of a Dutch undisclosed assignment requires either an authentic deed or a private document registered with the tax authorities (a register not accessible to the public). ${ }^{32}$

While deformalisation of assignment laws facilitates trading in debt generally, it also supports more specific developments within commodification of private debt, namely the growing significance of financing techniques based on assignment of receivables. Indeed, deformalisation has often been expressly motivated by promotion of techniques such as factoring (i.e. conversion of trade receivables into cash by selling them to a finance company, a factor) and, most particularly, securitisation (i.e. pooling together of receivables from mortgages or other loans, to be refinanced, typically off the originator's balance sheet, by issuing debt securities in capital markets). ${ }^{33}$ For example, this motive and 'the competitive position of the Dutch financial market' were present in the parliamentary proceedings resulting in the introduction of undisclosed assignment. ${ }^{34}$ The clearest cases, though, are the special laws enacted in several jurisdictions on securitisation. Typically, those laws have abolished formalities regarding assignment of claims within their scope of application, so as to facilitate securitisation transactions. ${ }^{35}$

Law on securitisation is of particular interest to this article. In the modern sense, securitisation emerged in the United States in the 1970s and in Europe about a decade later. ${ }^{36}$ As discussed in sections III.B-C below, securitisation and certain other financing techniques used in connection with it have brought wholly new aspects to commodification of private debt, especially in terms of distribution and magnitude of risk. Those aspects should lead one to ask at what cost the flexibility and profit opportunities brought by further commodification are gained. All in all, securitisation is a particularly good example of law-based commodification because its feasibility depends on the features of a broad regulatory framework, including regulation of buyers of securitised debt (i.e. investors in debt securities).

\footnotetext{
${ }^{30}$ Lebon, n. 2 above, at 389-391; Salomons, n. 28 above, at 644-645; E.-M. Kieninger, 'Evaluation: a common core? Convergences, subsisting differences and possible ways for harmonisation', in E.-M. Kieninger (ed.), Security Rights in Movable Property in European Private Law (Cambridge University Press, 2004), 647-673, at 649. The relevant provisions are currently found in Articles L. 313-23 et seq. of the Code monétaire et financier.

${ }^{31}$ Articles 1321 et seq. On security (nantissement) over receivables, see Articles 2355 et seq.

${ }^{32}$ Lebon, n. 2 above, at 392-393; Salomons, n. 28 above, at 643-644. See Article 3:94 of the Burgerlijk Wetboek. In fact, the new para. 3 of Article 3:94 reintroduced undisclosed assignment, for the Burgerlijk Wetboek of 1992 had discontinued the Dutch tradition of allowing assignments on an undisclosed basis. See Flessner and Verhagen, n. 2 above, at 26-27.

${ }^{33}$ Salomons, n. 28 above, at 640. For a history of factoring, see B. Bjørn, Factoring - A Comparative Analysis: The legal and practical implications of factoring as practised in the United States, England and Denmark (DJØF

Publishing, 1995), at 13-28. On the origins of securitisation, see V. Kothari, Securitization: The Financial Instrument of the Future (John Wiley \& Sons, 2006), at 108-111.

${ }^{34}$ F.M.J. Verstijlen, 'General Aspects of Transfer and Creation of Property Rights including Security Rights', in U. Drobnig, H.J. Snijders and E.-J. Zippro (eds.), Divergences of Property Law, an Obstacle to the Internal Market? (Sellier European Law Publishers, 2006), 17-35, at 24-25.

${ }^{35}$ Salomons, n. 28 above, at 645, 652-655. The first European jurisdiction to enact such legislation was France in 1988. The relevant provisions are currently found in Articles L. 214-167 et seq. of the Code monétaire et financier. Salomons notes that these laws appeared initially to be exclusively a Southern European phenomenon.

${ }^{36}$ Kothari, n. 33 above, at 109-110, 116. See N. Fligstein and A. Goldstein, 'A Long Strange Trip: The State and Mortgage Securitization, 1968-2010', in K. Knorr Cetina and A. Preda (eds.), The Oxford Handbook of the Sociology of Finance (Oxford University Press, 2014), 339-356.
} 


\section{Analysis: Modes of Commodification}

\section{A Propertification}

The above discussed historical points expose one particularly clear mode of commodification of private debt. This can be called propertification because it consists in a process where debt (as receivables or claims) acquires characteristics typical of a private property right. No universal definition exists of a private property right, but Max Weber's ideas on property as a kind of social relationship, and especially his notion of 'free property' offer a helpful starting point. For Weber, property belongs to 'closed' social relationships, i.e. relationships in which 'participation of certain persons is excluded, limited, or subjected to conditions' and 'monopolized advantages' are guaranteed in one way or another. More precisely, property involves 'appropriation'. In Weber's terms, appropriated advantages are 'rights', rights that can be inherited are 'property', and property that can be acquired (and disposed of) by voluntary agreement is 'free property'. ${ }^{37}$

It appears correct to equate 'free property' to private property rights because the latter are typically characterised by their erga omnes effects, ${ }^{38}$ and because property law typically deals with transfer as well as use of property. ${ }^{39}$ Accordingly, two standards emerge for propertification of private debt, namely transferability (or 'disposability') and after-transfer exclusiveness (or 'closedness'). Transferability means that the initial creditor (transferor) is capable of passing the creditor position to a prospective new creditor (transferee) by way of an agreement or other disposition. Aftertransfer exclusiveness means that the transferee's creditor position is protected against anyone who might be able to contest it. With that protection in place, the transferor cannot cancel or frustrate the transfer, the debtor cannot discharge the debt by paying the transferor, and the receivables are beyond the reach of the transferor's creditors and potential subsequent transferees.

As the discussion in section II indicated, transferability and after-transfer exclusiveness are results of long and gradual development, rather than necessary qualities of debt. To be sure, a high degree of both transferability and after-transfer exclusiveness is required so that debt can be reliably used as an object of commercial and financial transactions. In this way, propertification has changed debt as a legal institution, developing its 'enabling' or 'empowering' side. ${ }^{40}$ Accordingly, Weber mentions assignment and negotiable instruments as legal institutions, part of 'that legal state of affairs which is required by advanced and completely commercial social intercourse' and 'indispensable for a modern capitalistic society'. ${ }^{41}$

\footnotetext{
${ }^{37}$ Weber, n. 27 above, vol 1, at 43-44. See Swedberg n. 5 above, at 78-80.

${ }^{38}$ S. van Erp, 'Comparative Property Law', in M. Reimann and R. Zimmermann (eds.), The Oxford Handbook of Comparative Law (Oxford University Press, 2008), 1043-1070, at 1051-1052.

${ }^{39}$ U. Mattei, Basic Principles of Property Law: A Comparative Legal and Economic Introduction (Greenwood Press, 2000), at 99-100. Mattei writes: 'While use justifies the economic value of a given property [...] transfer is the mechanism through which the value (both individual and social) of property becomes concrete.'

${ }^{40}$ See Swedberg, n. 5 above, at 75-76.

${ }^{41}$ Weber, n. 27 above, vol. 2, at 681-682.
} 
The notion of debt as property, as such, is older, though. In opposition to the non-transferability dogma held by the humanists (after the glossators and the commentators), the natural lawyers regarded assignment as the full transfer of a right. They understood assignment 'as the transfer of ownership of res incorporales and systematically juxtaposed it with the transfer of ownership of res corporales', thus drawing a 'functional parallel between transfer of ownership and assignment'. ${ }^{42}$ Such a parallel implies recognition of the property nature of debt.

\section{B Impersonalisation}

Propertification, as defined above, goes hand in hand with standardisation of debt relations. In particular, transferability presupposes that obligations between persons $\mathrm{A}$ and $\mathrm{B}$ on the one hand, and between persons $\mathrm{A}$ and $\mathrm{C}$ on the other, can be identical or at least fundamentally similar. This stands in sharp contrast to the old non-transferability dogma, according to which 'the action arising from the obligation hinges on the bones and entrails of the creditor and can no more be separated from his person than the soul from the body'. ${ }^{43}$ Further standardisation follows from law providing that the debtor must be able to raise the same defences against the transferee as were available against the transferor, and that payment to the transferor must discharge the debt if the debtor was unaware of the transfer. ${ }^{44}$ All in all, standardisation entails impersonalisation of debt relations in that the identity of the creditor is generally irrelevant to the debtor. ${ }^{45}$ In practice, the debtor often anticipates that the initial creditor does not intend to remain the creditor until the debt is paid.

Impersonalisation through standardisation has changed debt as a legal institution in a way that is likely to find resonance in broader accounts of legal, economic and societal change. For example, consider Ferdinand Tönnies' classic distinction between two types of social grouping, Gemeinschaft (community) and Gesellschaft (civil society), with 'diametrically opposed systems of law'. In Gemeinschaft law, 'people are related to each other as natural members of a whole', whereas in Gesellschaft law, 'as individuals they are entirely independent of one another and enter into relationships only of their own free will'. According to Tönnies, 'property' belongs to both systems of law, but manifests itself differently in their respective contexts, namely as 'possession' in a Gemeinschaft context, and as 'wealth' in a Gesellschaft context. For him, possession 'is entirely one with the individual and bound up with him and his way of life', whereas wealth 'can be divided and combined' and 'alienated or disposed of'. ${ }^{46}$ Gemeinschaft and Gesellschaft can be kept separate only in theory, though. In reality, their characteristics are always mixed, while of course

\footnotetext{
${ }^{42}$ Zimmermann, n. 12 above, at 65. Here, Zimmermann refers in particular to Christian Wolff and Joachim Georg Darjes.

${ }^{43}$ Ibid., at 58 .

${ }^{44}$ See ibid., at 66.

${ }^{45}$ Impersonalisation through standardisation does not diminish the relevance of the identity of the debtor to the creditor, since the likelihood of payment or other recovery would generally vary between different debtors. However, use of security rights may have that effect to a limited extent. This is so because information on the encumbered assets (collateral) and enforceability of the security right substitutes for information on the debtor. See H.W. Fleisig, 'Economic Functions of Security in a Market Economy', in J.J. Norton and M. Andenas (eds.), Emerging Financial Markets and Secured Transactions (Kluwer Law International, 1998), 15-38, at 19.

${ }^{46}$ F. Tönnies, Community and Civil Society, ed. J. Harris, transl. J. Harris and M. Hollis (Cambridge University Press, 2001), 187-189.
} 
historically, shifts can be observed from characteristics of Gemeinschaft to those of Gesellschaft. ${ }^{47}$ The shift from property as possession to property as wealth is analogous to the shift from 'personal' to 'impersonal' debt. Interestingly, Tönnies describes the law relating to commercial obligations of his time, which to him exemplified Gesellschaft law, as follows: 'Actions and claims change hands like goods or coins, so that whatever is subtracted on one side is added to the other, just as in simple arithmetic. $^{48}$

Besides impersonalisation through standardisation discussed above, yet another kind of impersonalisation of debt relations exists, one that is prone to produce undesirable consequences. This involves the diminishing relevance to the creditor of the identity and circumstances of the debtor. That effect is well known in the context of securitisation, more precisely in the initial phase of securitisation, i.e. origination of loans. There, lenders and brokers representing them may think that potential debtor defaults are not their problem, because the loans made will be sold to securitisers, and the risks passed on even further in the securitisation chain, to investors in capital markets.

This kind of impersonalisation is worrying because it reduces lenders' main incentive to ensure that borrowers are capable of repaying their loans. Worse, it may incentivise predatory lending practices. ${ }^{49}$ The threat is not merely theoretical. Indeed, abuses in mortgage origination were one of the causes of the United States subprime mortgage securities market collapse, which sparked the global financial crisis. In Robert J. Shiller's words:

Borrowers were given mortgages they couldn't afford or the wrong kind of mortgages. [...] Brokers would often talk clients into buying large homes with adjustable-rate mortgages, without clearly informing them that the rates would likely go up and the homes become unaffordable. [...] The weaknesses in the mortgage origination market - and in the behaviour of certain market participants-reflects a genuine deficiency in the modern financial system and a prime site for innovative solutions..$^{50}$

Yet the situation is difficult to remedy by regulation because ' $[t]$ here remains so much in the process of issuing a mortgage that simply cannot be seen and policed by the government'. ${ }^{51}$ True, any solution focusing merely on the loan origination phase will be insufficient. Therefore, incentives present in that phase should be controlled by dealing with the securitisation chain in its entirety.

\footnotetext{
${ }^{47}$ See Frerichs and Juutilainen, n. 8 above, at 95-96.

48 Tönnies, n. 46 above, at 187.

${ }^{49}$ See T. Wilson, 'The Responsible Lending Response', in T. Wilson (ed.), International Responses to Issues of Credit and Over-indebtedness in the Wake of Crisis (Ashgate, 2013), 109-131, at 121-122.

${ }^{50}$ R.J. Shiller, Finance and the Good Society (Princeton University Press, 2012), at 51. Shiller notes the delicateness of mortgage origination due to the typical imbalance between 'the least financially informed party, the future homeowner(s), and sophisticated professional financial representatives'. He does not, at least explicitly, take sides in the debate whether securitisation and the so-called originate-to-distribute model actually lowered lending standards. On that debate, see O. Akseli, 'Securitisation, the Financial Crisis and the Need for Effective Risk Retention', (2013) 14 European Business Organization Law Review 1-27, at 6-7.
}

${ }^{51}$ Shiller, n. 50 above, at 51. 


\section{Risk Abstraction}

A third mode of commodification of private debt, risk abstraction, like certain aspects of impersonalisation discussed above, is found in the securitisation chain. This concerns creation of financial products to be sold to investors in capital markets. Creation of financial products involves detachment of risk from actual debt relations, combination and other manipulation of those risks, and 'packaging' them into securities. Risk abstraction manifests itself even with the simplest residential mortgage backed securities (RMBSs). Accordingly, trade in RMBSs enables 'the extension of social relations across time and space', promising 'the transformation of the residential mortgage — a spatially fixed, messy, and illiquid commodity — into a tradeable, mobile, and liquid financial asset'. ${ }^{52}$

Risk abstraction has dramatically increased through further financial innovation and ever more engineered financial products, including collateralised debt obligations (CDOs) and credit default swaps (CDSs). In the mortgage securitisation context, CDOs may involve combining in the same debt security mortgage payments of many items of real estate located in many places, but separate in the security different 'tranches' with different risk and return profiles to cater for different investor appetites. CDSs are derivatives and, in effect, tradeable insurance policies against default of a designated security, such as a CDO. ${ }^{53}$ In the United States, the complexity of financial products grew vastly in the years preceding the credit crunch of 2007-2008, while the quality of mortgages securitised deteriorated.

Like impersonalisation, risk abstraction is partly worrying. In the case of risk abstraction, this is due to systemic risk, i.e. the possibility of systemic collapse. Adair Turner discusses some of the causes of the United States subprime mortgage securities market collapse as follows:

[T] he financial innovations of structured credit resulted in the creation of products - e.g. the lower credit tranches of CDOs or even more so of CDO-squareds - which had very high and imperfectly understood embedded leverage, creating positions in the trading books of banks which were hugely vulnerable to shifts in confidence and liquidity. ${ }^{54}$

\footnotetext{
${ }^{52}$ S. French and A. Leyshon, 'Dead Pledges: Mortgaging Time and Space', in K. Knorr Cetina and A. Preda (eds.), The Oxford Handbook of the Sociology of Finance (Oxford University Press, 2014), 357-375, at 372. French and Leyshon refer to 'risk abstraction' in the same context but in a somewhat broader sense (at 367).

${ }^{53}$ For a fuller yet succinct account of CDOs and CDSs, see Blyth, n. 3 above, at 28-29.

54 Turner, n. 3 above, at 20. Turner also notes that '[ $\mathrm{t}] \mathrm{o}$ an increasing extent, credit securitised and taken off one bank's balance sheet, was not simply sold through to an end investor, but: bought by the propriety trading desk of another bank; and/or sold by the first bank but with part of the risk retained via the use of credit derivatives; and/or "resecuritised" into increasingly complex and opaque instruments (e.g. CDOs and CDO-squareds); and/or used as collateral to raise short-term liquidity' (at 16, bullet points omitted). See Blyth, n. 3 above, at 29-31. Blyth explains how CDOs that were meant to eliminate the correlation between assets ended up creating it, and how CDSs that were meant to insure against correlation risks ended up amplifying the problem in a way that resulted in systemic collapse.
} 
In a Polanyian perspective, arguably, risk abstraction involves disembedding of debt relations. ${ }^{55}$ Indeed, the personal, social, political and perhaps even religious 'bonds' inherent in or affecting a debt relation will mostly not follow when the risk of that debt relation is abstracted into a financial product. Further, the global financial crisis has shown the destructive capacity of risk abstraction. Then again, regulation may be seen as a way to re-embed debt relations.

\section{Future: Incompleteness and Indeterminate Course of Commodification}

\section{A Cross-Border Assignment of Claims}

Commodification of private debt cannot be regarded as complete in terms of any of the three modes discussed above. The course of commodification is indeterminate, but to some degree steerable by future law-making. One illustration to that effect concerns cross-border assignments of claims in the European Union. Its gist is that propertification is underdeveloped in cross-border (or internal market) contexts, as compared to domestic (or Member State) contexts.

The root cause of cross-border problems are divergences of substantive law between Member States. Some of these divergences were briefly discussed in sections II.B-C above, so suffice it to note that they often concern requirements for effectiveness of an assignment against third parties (other than the assigned debtor), especially the assignor's creditors or subsequent assignees. The problems are greatly exacerbated by the fact that even conflict rules (i.e. private international law rules) on third-party effectiveness vary between Member States. Article 14 of Regulation 593/2008 (Rome I) concerns assignment of claims but only deals with relations between the assignor and the assignee (para. 1) and between the assignor or the assignee and the assigned debtor (para. 2). A conflict rule on third-party relations was omitted from Article 14 because the negotiating Member States could not agree on what would be the appropriate conflict rule for that purpose. ${ }^{56}$ As a result, different Member States use different conflict rules on third-party relations, the main options being the law governing the contract of assignment, the law of the assignor's habitual residence and the law governing the assigned claim. ${ }^{57}$

The combined effect of divergences of substantive law and conflict rules between Member States can be understood in terms of incomplete and insufficient propertification, particularly as lacking after-transfer exclusiveness. That is to say, claims often fail to function like property in cross-border contexts, since the effectiveness of assignments against third parties is uncertain, so that the assignee may lose the claim assigned. To be on the safe side, first, the parties to an assignment should know all jurisdictions whose courts may eventually have to adjudicate on third-party effectiveness. Second, the parties should fulfil the requirements for third-party effectiveness under all substantive laws to which the conflict rules of those jurisdictions point. The problem is that it

\footnotetext{
${ }^{55}$ See F. Block, 'Introduction', in K. Polanyi, The Great Transformation: The Political and Economic Origins of Our Time (Beacon Press, 2001), xviii-xxxviii, at xxiii-xxix.

${ }^{56}$ P.M.M. van der Grinten, 'Article 14 Rome I: A Political Perspective', in R. Westrik and J. van der Weide (eds.), Party Autonomy in International Property Law (Sellier European Law Publishers, 2011), 145-163, at 154-161.

${ }^{57}$ See BIICL, n. 24 above, at 12-13, 19-22.
} 
may be unknowable beforehand what the relevant jurisdictions are, and the number of potentially applicable substantive laws may grow unmanageable. ${ }^{58}$

These issues are found in the Commission's Capital Markets Union action plan, ${ }^{59}$ and it is probably widely thought that 'nearly every clear cut rule whatever connecting factor it chooses is better than the present state of affairs' ${ }^{60}$ Nevertheless, it seems unlikely that a common European conflict rule will be introduced any time soon. Besides different views among Member States, different branches of the financial industry appear to favour different conflict rules. ${ }^{61}$ The question arises whether it would, after all, be easier to unify or harmonise substantive law on assignment of claims, and thus avoid examining complex combinations of substantive rules and conflict rules based on different connecting factors. ${ }^{62}$ Either solution would advance propertification, which appears advisable for the reliability of commercial and financial transactions.

\section{B Simple, Transparent and Standardised (STS) Securitisation}

The global financial crisis hit the European securitisation market hard. Issuance to third-party investors dropped from EUR 477.6 bn in 2006 to 'almost nothing' in $2009 .{ }^{63}$ The current regulatory framework is generally thought to hold back growth of the securitisation market. The European financial industry considers the regulatory burden excessive, arguing that 'the current regulatory treatment was calibrated to reflect the weak performance of some US securitised assets - notably, US sub-prime mortgages - during the financial crisis, rather than the strong performance of European securitisation'. ${ }^{64} \mathrm{Be}$ that as it may, in the terminology of this article, regulation that constricts securitisation amounts to de-commodification of private debt.

The Commission has chosen to pay heed to the financial industry. As part of the Capital Markets Union project, the Commission is proposing a securitisation package, including a Securitisation Regulation and amendments to the Capital Requirements Regulation. ${ }^{65}$ Through the package, the

\footnotetext{
${ }^{58}$ T. Juutilainen, 'Coherence through Uniform Private International Law of Property', in P. Letto-Vanamo and J. Smits (eds.), Coherence and Fragmentation in European Private Law (Sellier European Law Publishers, 2012), 101-123, at $108-109$.

${ }^{59}$ Communication $\operatorname{COM}(2015) 468$ final, n. 11 above, at 23, 30.

${ }^{60}$ E.-M. Kieninger, 'Collateralisation of Contracts', (2013) 9 European Review of Contract Law 430-454, at 438.

${ }^{61}$ T.C. Hartley, 'Choice of Law Regarding the Voluntary Assignment of Contractual Obligations under the Rome I Regulation', (2011) 60 International and Comparative Law Quarterly 29-59, at 51-52.

62 On possible points of reference for such discussions, see Lurger, n. 24 above, at 105-107.

${ }^{63}$ Association for Financial Markets in Europe (AFME), High-quality securitisation for Europe: The market at a crossroads (June 2014), at 14, available at http://www.afme.eu/en/reports/publications/reports/afme-high-qualitysecuritisation-for-europe. AFME defines securitisation as 'the pooling together of cash-generating assets, such as mortgages, auto loans or SME loans, created by banks and initially funded on their balance sheets, and funding these assets instead by issuing bonds in the capital markets' (at 5).

${ }^{64}$ Ibid., at 4.

${ }^{65}$ Proposal for a Regulation of the European Parliament and of the Council laying down common rules on securitisation and creating a European framework for simple, transparent and standardised securitisation and amending Directives 2009/65/EC, 2009/138/EC, 2011/61/EU and Regulations (EC) No 1060/2009 and (EU) No 648/2012, COM(2015) 472 final, 30 September 2015, available at https://ec.europa.eu/transparency/regdoc/rep/1/2015/EN/1-2015-472-EN-F11.PDF; Proposal for a Regulation of the European Parliament and of the Council amending Regulation (EU) No $575 / 2013$ on prudential requirements for credit institutions and investment firms, COM(2015) 473 final, 30 September 2015, available at https://ec.europa.eu/transparency/regdoc/rep/1/2015/EN/1-2015-473-EN-F1-1.PDF.
} 
Commission aims, among other things, ' $[\mathrm{t}]$ o revive markets on a more sustainable basis so that STS securitisation can act as an effective funding channel to the economy'. 'STS' stands for 'simple, transparent and standardised'. Securitisation products fulfilling the STS criteria are regarded as 'safer and simpler', and the prudential treatment concerning them would be amended accordingly for banks and investment firms, and later but with the same effective date for insurers ('more risksensitive provisions on regulatory capital requirements'). This is expected to make investing in STS securitisation products more attractive for actors established in the European Union. ${ }^{66}$

A securitisation market revival, as attempted by the Commission, could be understood as recommodification of private debt. Thus, a crucial question is whether the Commission adequately deals with the worrying aspects of impersonalisation and risk abstraction pointed out in sections III.B-C above. Only a few preliminary observations are possible here. The proposed Securitisation Regulation would address those worrying aspects to some extent, possibly safeguarding the quality of securitised loans and making it easier for investors to analyse and understand the risks of securitisation products. This would be foremost due to the STS criteria themselves (Articles 6-13) and rules on due diligence for investors (Article 3), risk retention (Article 4) and transparency (Article 5).

The future adequacy of the STS criteria is difficult to assess, though. One reason for this is that the Commission leaves open the possibility of extending the criteria in the future. In the proposed Securitisation Regulation, only 'true sale' securitisations qualify as STS, whereas synthetic securitisations do not. In a synthetic securitisation, 'the credit risk related to the underlying exposures is transferred by means of a guarantee or derivative contract', which 'introduces an additional counterparty credit risk and potential complexity'. Nevertheless, following the work of international and European bodies, the Commission 'will assess whether some synthetic securitisations that have performed well during the financial crisis and that are simple, transparent and standardised should be able to meet the STS requirements' ${ }^{67}$ Simplicity is relative, as indeed is transparency. This can be read as an example of the indeterminacy of commodification of private debt.

\section{Conclusion}

The overarching aim of this special issue is to unravel the European community of debt, exploring the diverse bonds (here, in a sociological rather than financial sense) that connect states and peoples, and enterprises and individuals. The emphasis is on the role of law in transnationalisation of debt relations, yet keeping in mind that communities are bound together by solidarity, so that transnational communities of debt presuppose transnationalisation of solidarity. This article has

\footnotetext{
${ }^{66}$ European Commission - Fact Sheet, A European Framework for Simple and Transparent Securitisation, 30 September 2015, available at http://europa.eu/rapid/press-release_MEMO-15-5733_en.htm. See Proposal COM(2015) 472 final, n. 65 above, at 15. The Commission emphasises that STS does not mean risk free, but means that a number of criteria are respected and 'a prudent and diligent investor will be able to analyse the risk involved'. For analysis and critique, see S.L. Schwarcz, 'Securitization and Post-Crisis Financial Regulation', (2016) 102 Cornell Law Review Online 115-139, at 121-129, available at http://cornelllawreview.org/files/2016/10/SchwarczOnlineEssayfinal.pdf. ${ }^{67}$ Proposal COM(2015) 472 final, n. 65 above, at 15.
} 
contributed to the aim by looking into bonds that private debt implies for the parties in that relationship and for societies at large. In particular, the article has focused on the nature of debt as a commodity, i.e. a tradeable asset. What justifies this focus in the context of the special issue is that commodification of debt is a prerequisite for circulation and large-scale transnationalisation of debt, and thus formation of transnational communities of debt.

It would be incorrect to assume that commodification of private debt has only been about quantitative change, i.e. increasing volumes of trading in debt. Instead, as the brief analysis of historical material in this article indicates, the legal institution of debt and the economic and social functions of debt have significantly changed in the process. The three modes of commodification distinguished in the article - propertification, impersonalisation and risk abstraction - capture the main aspects of those changes and explain how private debt has developed into the kind of tradeable asset that it is today.

It would be equally incorrect to assume that commodification of private debt is now complete. Indeed, the process is likely to continue in terms of all three modes. Importantly, as the examples of cross-border assignments of claims and the European securitisation market show, future lawmaking in Europe is in a position to partly decide how the story of commodification will continue. This observation opens space for normative insights. From the viewpoint of the European community of debt, commodification of private debt can be both insufficient and excessive at the same time. This is less paradoxical than it may sound. Commodification is insufficient where debt, in the shape of claims or receivables, cannot be reliably used as an object of commercial and financial transactions. Commodification is excessive where it incentivises abuse or causes a risk of systemic collapse. ${ }^{68}$

Future law-making in matters like these may be crucial for the self-preservation of the European community of debt (and of fate, and of law). Inactivity or wrong decisions, should these cumulate over time, may cause that community's cohesive bonds of solidarity to falter. Insufficient commodification implies lost opportunities in terms of prosperity, and is likely to reduce the chances and the will to commit to economic activity, while excessive commodification may induce crises capable of putting transnational solidarity to extreme tests.

\footnotetext{
${ }^{68}$ In general terms, this point resembles Driesen's economic dynamic theory, which 'focuses on the shape of change over time' and 'adopts avoidance of systemic risk while keeping open a reasonably robust set of economic opportunities as a minimum governmental goal'. See D.M. Driesen, The Economic Dynamics of Law (Cambridge University Press, 2012), at 5 .
} 